\title{
Energy allocation in a reef coral under varying resource availability
}

\section{Journal Article}

Author(s):

Leuzinger, Sebastian; Willis, Bette L.; Anthony, Kenneth R.N.

Publication date:

2012-01

Permanent link:

https://doi.org/10.3929/ethz-b-000412186

Rights / license:

In Copyright - Non-Commercial Use Permitted

Originally published in:

Marine Biology 159(1), https://doi.org/10.1007/s00227-011-1797-1 


\title{
Energy allocation in a reef coral under varying resource availability
}

\author{
Sebastian Leuzinger $\cdot$ Bette L. Willis • \\ Kenneth R. N. Anthony
}

Received: 3 February 2011/ Accepted: 10 September 2011/Published online: 6 October 2011

(C) Springer-Verlag 2011

\begin{abstract}
An organism's pattern of resource allocation to reproduction and growth over time critically impacts on its lifetime reproductive success. During times of low resource availability, there are two fundamental, mutually exclusive strategies of energy investment: maintenance of somatic tissues to support survival and later reproduction or investment into an immediate reproductive event at the risk of subsequent death. Here, we examine energy allocation patterns in the coral Montipora digitata to determine whether energy investment during periods of resource shortage favours growth or reproduction in a sessile, modular marine species. We manipulated light regimes (two levels of shading) on plots within a shallow reef flat habitat (Orpheus Island, Great Barrier Reef, Australia) and quantified energy uptake (rates of net photosynthesis), energy investment into reproduction $\left(E_{R}\right)$, tissue growth per unit surface area $\left(E_{T}\right)$ and energy channelled into calcification $\left(E_{C}\right)$. With declining resource availability (i.e. reduced photosynthesis), relative energy investment shifted from high $(\sim 80 \%)$ allocation to tissue growth $\left(E_{R}: E_{T}: E_{C}=11: 81: 8 \%\right)$ to an increasing proportion channelled into reproduction and skeletal growth
\end{abstract}

Communicated by R. H. Richmond.

S. Leuzinger $(\bowtie)$

ETH Zurich, Institute of Terrestrial Ecosystems,

8092 Zurich, Switzerland

e-mail: Sebastian.Leuzinger@env.ethz.ch

B. L. Willis

School of Tropical and Marine Biology, and the ARC

Centre of Excellence for Coral Reef Studies, James Cook

University, Townsville, QLD 4811, Australia

K. R. N. Anthony

Australian Institute of Marine Science,

Townsville, QLD 4810, Australia
(20:31:49\%). At the lowest light regime, calcification was maintained but reproduction was halted and thus energy content per unit surface area of tissue declined, although no mortality was observed. The changing hierarchy in energy allocation among life functions with increasing resource limitation found here for an autotrophic coral, culminating in cessation of reproduction when limitations are severe, stands in contrast to observations from annual plants. However, the strategy may be optimal for maximising fitness components (growth, reproduction and survival) through time in marine modular animals.

\section{Introduction}

During its lifetime, every organism allocates available energy in a series of physiological trade-offs that, in combination with evolutionary trade-offs, determine its reproductive strategy. Examples of strategic decisions that arise as a consequence of these trade-offs and form part of an organism's life history are 'How often do I reproduce?', 'How much energy do I invest into one reproductive event?' and 'How much do I grow before puberty or between periods of reproduction?' (Fisher 1930; Williams 1966; Stearns 1989). Essentially, organisms invest their energy in continuous trade-offs between somatic growth (broadly including maintenance and defence) and reproduction, which in many species includes the possibility of asexual reproduction (Nespolo et al. 2009). In a stochastic environment, physiological trade-offs vary through time, reflecting variations in resource availability (Fischer et al. 2011). An organism under severe resource limitation will respond according to one of two fundamental strategies of energy allocation: (1) increase investment into reproduction in the short-term and subsequently risk death as vital resources are depleted or (2) maintain somatic tissues to withstand a period of resource scarcity and 
acquire resources for reproduction later in life (e.g. Stearns 1989; Fischer et al. 2009). We define the term 'energy allocation' as the partitioning between the various investment options (growth, sexual reproduction, defence) and the term 'energy budget' as the sum of all fluxes of energy into and out of an organism over a defined time period.

Experimental manipulation of resources has been used widely as a tool to investigate energy allocation or, more generally, life-history strategies of organisms (e.g. Calow 1987; DeAngelis and Gross 1992; Zera and Harshman 2001; Reekie et al. 2005; Gutow et al. 2007). When resources become increasingly limiting, a general trend of enhanced energy investment into survival at the cost of reproduction can be observed in birds (Kaitala 1991), insects (Ellers and van Alphen 1997) and isopods (Gutow et al. 2007). However, once a critical threshold is reached so that the probability of survival approaches zero, a terminal reproductive effort is predicted ('terminal investment theory', Velando et al. 2006), for which there is both experimental and theoretical support (e.g. Stelzer 2001; Fischer et al. 2009). Thus, a concave relationship between resource availability and reproductive investment has been predicted, with high investments in reproduction when resources are either very low or abundant.

Most studies of energy allocation at various resource levels have focused on small, unitary organisms with short generation times and predominant sexual reproduction, for example the water flea Daphnia sp. (Elendt 1989; Noonburg et al. 1998) and insects (Boggs 2009). For modular organisms, such as reef corals or plants, frequent asexual reproduction through fragmentation adds to the complexity of their life-history trade-offs, because the cost of asexual reproduction is generally lower than that of sexual reproduction (Maynard Smith 1971). Energy allocation in plants is relatively well documented. For example, perennial species reduce their investment into reproduction in response to resource limitation, while annual species tend to increase reproductive allocation under the same conditions, which is in line with the theory of 'terminal investment' before death as described above (Chiariello and Gulmon 1991). In cnidarians, most studies have concentrated on energy budgets rather than energy allocation patterns (Edmunds and Spencer Davies 1986; McCloskey et al. 1994; Riegl and Branch 1995; Edmunds 2007), some focusing on energy acquisition and investment under different scenarios of resource availability (Goreau and Goreau 1959; Stromgren 1987; Spencer Davies 1991; Cullen and Lesser 1991; Anthony and Fabricius 2000). None of these studies, however, formally examine strategies of energy allocation to reproduction in cnidarians.

Most symbiotic reef corals rely on photoautotrophy as their primary energy source (Muscatine 1990), although heterotrophy may contribute a significant proportion of the energy and nutrients acquired (Grottoli et al. 2006; Anthony and Fabricius 2000). For species that rely predominantly on autotrophy, such as M. digitata (Anthony 1999), their energy uptake can be estimated comprehensively through measurements of oxygen fluxes (i.e. respirometry; McCloskey et al. 1978; Chalker et al. 1983) and their energy availability manipulated effectively through alteration of the light regime (Rogers 1979; Wellington 1982).

The determination of energy allocation patterns in corals requires estimates of four pathways for energy investment: (1) somatic growth and maintenance, (2) growth and maintenance of reproductive tissues and gametes, (3) calcification and (4) excretion. Skeletal growth (calcification) is traditionally measured by direct measurements of linear extension (Buddemeier 1976; Logan and Tomascik 1991; Lough and Barnes 1997) or by measuring buoyant weight (Spencer Davies 1989). Energy invested into tissue growth can be measured based on estimates of surface area multiplied by the area-specific energy content of somatic tissue (Anthony et al. 2002). Lipids constitute the primary energetic component of coral tissue (e.g. Stimson 1987) and are generally a good predictor of resource allocation to somatic and reproductive tissues in corals (Leuzinger et al. 2003). This measure inevitably correlates with egg size and number, another commonly used approach to quantify reproductive effort in corals (Ward and Harrison 2000).

The aim of this study was to determine how resource allocation to growth and reproduction changes in response to resource limitation (low light) in M. digitata, an abundant intertidal reef coral on the Great Barrier Reef. Based on the predicted concave relationship between resource availability and reproductive investment, we test the specific hypothesis that colonies of $M$. digitata subjected to resource limitation will decrease their ratio of reproductive output to growth, as resources become scarce under experimental regimes of reduced light. Understanding energy allocation strategies under varying light regimes (e.g. as a function of episodic turbidity following flood events or cloud cover associated with rainy seasons, Anthony et al. 2004) will provide insights into adaptive strategies maintaining the key fitness components of a perennial lifestyle of a modular marine invertebrate: that is its lifetime reproductive success, growth and space pre-emption of suitable habitat at a minimum risk of mortality.

\section{Materials and methods}

Study species

Montipora digitata, a branching, locally abundant intertidal reef flat coral, was selected because it forms large clonal stands 
and fragments naturally, making it ideal for experimental manipulation (Bachtiar 1994; Stobart 1994). Furthermore, because $M$. digitata relies predominantly on photoautotrophy as its energy source, experimental manipulation of its light field is a good proxy for resource availability. It is a broadcast spawner with one main spawning period in spring, and a second, minor reproductive event after the full moon in the southern autumn (Stobart et al. 1992).

\section{Study site and period}

The study site was located in an area of the intertidal zone dominated by $M$. digitata in Pioneer Bay, which is adjacent to Orpheus Island, in the Great Barrier Reef, Australia $\left(18^{\circ} 35^{\prime} \mathrm{S}, 146^{\circ} 20^{\prime} \mathrm{E}\right)$. The experimental area was ca. $0.9 \mathrm{~m}$ above lowest astronomical tide, and the highest tides resulted in a water depth of about $3 \mathrm{~m}$. Field manipulations were conducted from November 2000 until November 2001. Laboratory-based components of the study (e.g. respirometry) were carried out in holding tanks supplied with flow-through seawater at the adjacent Orpheus Island Research Station.

\section{Manipulative field experiments}

To investigate changes in the biochemical composition of tissues of $M$. digitata in response to resource variation, healthy colonies $(n=36)$ of an average size of $10 \mathrm{~cm}$ by $10 \mathrm{~cm}$ by $10 \mathrm{~cm}$ were exposed to one of the three different light treatments: unshaded, half-shaded and shaded (12 colonies assigned to each light treatment). Colonies were collected haphazardly from the study site, ensuring that their sites of origin were $>3 \mathrm{~m}$ apart to increase the likelihood that their genotypes differed. Each colony was mounted on a plastic rack anchored on a terracotta tile (20 cm by $20 \mathrm{~cm}$ ), which was then carefully embedded in rubble at each of 36 haphazardly distributed plots. To manipulate light levels, twelve $80 \%$ shade cloths and 12 Laserlight ${ }^{\mathrm{TM}}$ screens $(60 \mathrm{~cm} \times 60 \mathrm{~cm})$ were fixed to metal stakes and haphazardly distributed, together with 12 unshaded control plots, in the zone where M. digitata was most abundant. Shade cloth and screens were cleaned weekly to ensure constant light levels. Down-welling irradiance in each of the plots approximated 50, 520 and 1,500 mmol photons $\mathrm{m}^{-2} \mathrm{~s}^{-1}$ under shaded, half-shaded and unshaded conditions, respectively, as measured at one metre depth on three different, cloudless days at around noon, using a Li $192 \mathrm{~S}$ cosine-corrected sensor connected to Li 1000 logger (Licor, Nebraska, USA).

To determine skeletal growth rates, three separate additional coral branches (approximately $10 \mathrm{~cm}$ long) were placed adjacent to each of the 36 experimental colonies. Each branch was fixed in a short piece of PVC tube and wedged in place with a nylon screw (12 mm inner diameter). The branch protruded by a few centimetres and was attached next to the experimental racks. Only the living part of the fragment $(>8 \mathrm{~cm})$ projecting beyond the edge of the tube was measured. Buoyant weight (Spencer Davies 1989) was measured before the fragments were exposed to the light treatments and then after 4 months. This period comprised part of both the wet and dry seasons, although previous studies have shown that growth rates of $M$. digitata do not depend on either the season or reproductive status (Heyward and Collins 1985). The plastic tubes and associated dead parts of each branch were weighed separately at the end of the study. The net increase in buoyant weight $\left(W_{b}\right)$ of the living part was converted to skeletal dry weight $\left(W_{\mathrm{sk}}\right)$, using the relationship.

$W_{\text {sk }}=1.73 W_{b}$, based on an experimental calibration for 5 branches $\left(R^{2}>0.98\right)$. The means of the three replicates per plot were used for the analyses of both linear extension and skeletal dry weight. The conversion from differences in dry weight $\left(\Delta W_{\text {sk }}\right)$ to measures of energy investment was based on Anthony and Fabricius (2000) and Anthony et al. (2002): the precipitation of $1 \mathrm{mg}$ of $\mathrm{CaCO}_{3}$ requires $5 \mu \mathrm{mol}$ ATP used for $\mathrm{Ca}^{2+}$ uptake through proton exchange, equating to $0.152 \mathrm{~J}$ (Zubay 1983). The value was standardised to the initial surface area $\left(S_{1}\right)$ and calculated for the experimental period. Therefore, the energy invested into skeletal growth $\left(E_{C}\right)$ for the four-month period was calculated as $E_{C}=\Delta W_{\mathrm{sk}} / S_{1} \cdot 0.152 \mathrm{~J} \mathrm{mg}^{-1}$.

\section{Biochemical analysis}

Changes in lipid weight per unit surface area and in lipid composition during the experimental period were used as proxies for both somatic and reproductive investment, with changes between samples taken immediately before and after spawning used as a measure of reproductive investment. A more detailed quantification of reproductive investment would also require information on the number of eggs per unit surface area. However, the assumption of a linear relationship between tissue energy lost during spawning and reproductive investment has been shown to adequately describe reproductive investment (Leuzinger et al. 2003). Sampling took place immediately before and after the main spawning in November 2000 and 2001, as well as in April 2001, immediately before the expected minor spawning event. Fragments of approximately $10 \mathrm{~cm}^{2}$ were used for lipid analysis. To express lipids per unit surface area, the area of live tissue was determined by measuring length and diameter of each branch and calculating its area based on simple cylindrical or cone geometries. Samples were then freeze-dried and ground to powder using a mortar and pestle. The extraction technique used was modified from the method described by Folch 
et al. (1957) and Harland et al. (1992), as described in Leuzinger et al. (2003). A subset of samples (November 2000 after spawning, April 2001 and November 2001 before spawning) was used for protein and carbohydrate analyses (protocols detailed in Leuzinger et al. 2003). Samples from before and after spawning originated from the same colonies. Use of lipid composition (neutral vs. polar lipids) in post-spawning somatic tissues has not been explored in corals, but there is evidence from studies of fish that this ratio represents the relative composition of reproductive versus structural lipids and thus functions as a proxy for reproductive energy investment (Busalmen et al. 1995). Accordingly, the ratio of neutral to polar lipids (hereafter called n:p lipid) was determined for samples before and after spawning by the Department of Primary Industries (DPI) Laboratory in Brisbane.

Respirometry experiments and monitoring of light levels

To determine the rates of photosynthesis as a function of irradiance (P-I curves) and rates of dark respiration, eight colonies were collected haphazardly from plots within each treatment (shaded, unshaded and half-shaded) after the treatment had been in place for 5 months. Clark-type oxygen electrodes (Cheshire Systems, Australia) were used to measure $\mathrm{O}_{2}$ fluxes simultaneously in five 2.5 - $\mathrm{L}$ chambers (see Anthony and Hoegh-Guldberg 2003). The total surface area of colonies placed in each chamber was approximately $100 \mathrm{~cm}^{2}$. The flow rate through the chambers was approximately $5 \mathrm{~cm} \mathrm{~s}^{-1}$. Chambers were submersed in running seawater to ensure a stable temperature regime. Oxygen concentrations were measured with Clarktype oxygen electrodes (Cheshire Systems, Adelaide, Australia) and logged with a DataTaker50 (Chesterland, Ohio, USA). Two metal-halide lamps (EYE, Japan, $400 \mathrm{~W}$ each) provided light with a spectrum close to that of sunlight. Light levels were increased by lowering the lamps over the chambers in 9 steps $(0,50,100,200,350,500$, $750,1,000,1,500 \mu \mathrm{mol} \mathrm{m} \mathrm{m}^{-2} \mathrm{~s}^{-1}$ ) and held constant at each level for $20 \mathrm{~min}$, during which the oxygen concentration was logged in intervals of $10 \mathrm{~s}$. Water temperature was monitored continuously and remained within the range of $23-25^{\circ} \mathrm{C}$. Chambers were continuously stirred and flushed for $4 \mathrm{~min}$ after incubation at every light level. To control for background oxygen fluctuations, one chamber was left without a coral in every run, and all measurements were corrected for background oxygen consumption/production that occurred in it. The model used to describe the P-I curves was the one most commonly used (Jassby and Platt 1976, Chalker 1981): $P_{\text {net }}=P_{m} \tanh \left(I / I_{k}\right)+R$, where $P_{\text {net }}$ expresses gross photosynthesis $\left(P_{m}\right)$ plus respiration ( $R$, negative by convention), $I$ the ambient light level and $I_{k}$ the light level where the initial slope of the curve intersects the horizontal asymptote.

Oxygen flux was converted to energy units (Joules) assuming that the evolution of $3 \mathrm{~mol}$ oxygen results in the synthesis of $1 \mathrm{~mol}$ glycerinaldehyde-3-phosphate with a combustion enthalpy of $-1.467 \mathrm{~J} \mathrm{~mol}^{-1}$. Thus, $P_{\text {net }}(\mu \mathrm{mol}$ $\left.\mathrm{O}_{2} \mathrm{~cm}^{-2} \mathrm{~h}^{-1}\right)$ equates to $0.489 \mathrm{~J} \mathrm{~cm}^{-2} \mathrm{~h}^{-1}\left(=E_{P \text { net }}\right)$. These values were divided by the photosynthetic quotient $(\mathrm{P} / \mathrm{Q}=1.1$, Muscatine 1990) but no further energy loss was assumed, since the biosynthesis of lipid, protein and carbohydrate from glycerinaldehyde-3-phosphate is highly efficient and does not entail energy losses of more than 5\% (Withers 1992).

\section{Environmental data}

To provide long-term light records, irradiance was recorded continuously on land using an upward pointing, cosine-corrected light sensor (DataFlow PAR sensor) approximately $400 \mathrm{~m}$ from the experimental area in the field. The actual light levels received by the colonies were estimated with the equation for light extinction in water (Kirk 1994) $I_{\mathrm{z}}=I_{0} \mathrm{e}^{-\mathrm{z} \psi \mathrm{c}}$, where $I_{z}$ is the light level at depth $z, I_{0}$ the light measured immediately below the water surface, $c\left(\mathrm{mg} \mathrm{l}^{-1}\right)$ the particle concentration and $\psi$ a coefficient relating the light extinction to the particle concentration $c\left(0.041 \mathrm{~m}^{-1} \mathrm{mg}^{-1}\right)$. $I_{O}$ was calibrated for the different treatments from light measurements that were made in the field.

\section{Data analysis}

To test the effect of the experimental light regimes on tissue composition, skeletal growth, respirometry parameters and the n:p lipid ratio, one-way ANOVAs were used for each time window, followed by Tukey's HSD tests for post hoc comparisons. The effects of spawning on changes in lipid, protein and carbohydrate levels were tested individually using Student's $t$ tests for paired samples. Data were log-transformed prior to analyses where assumptions of homogeneity of variance and normality were violated. The package ' $R$ ' (version 2.10.1, R Development Core Team 2007) was used for all analyses.

\section{Results}

Somatic tissue composition

After 4 months of changed light regimes, lipid content was 150 and $50 \%$ higher in the unshaded (around $6 \mathrm{mg} \mathrm{cm}^{-2}$ ) and half-shaded (around $4 \mathrm{mg} \mathrm{cm}^{-2}$ ) colonies, respectively, in comparison with shaded colonies $\left(2.4 \mathrm{mg} \mathrm{cm}^{-2}\right)$ (Fig. 1). After 12 months (immediately prior to the spring 


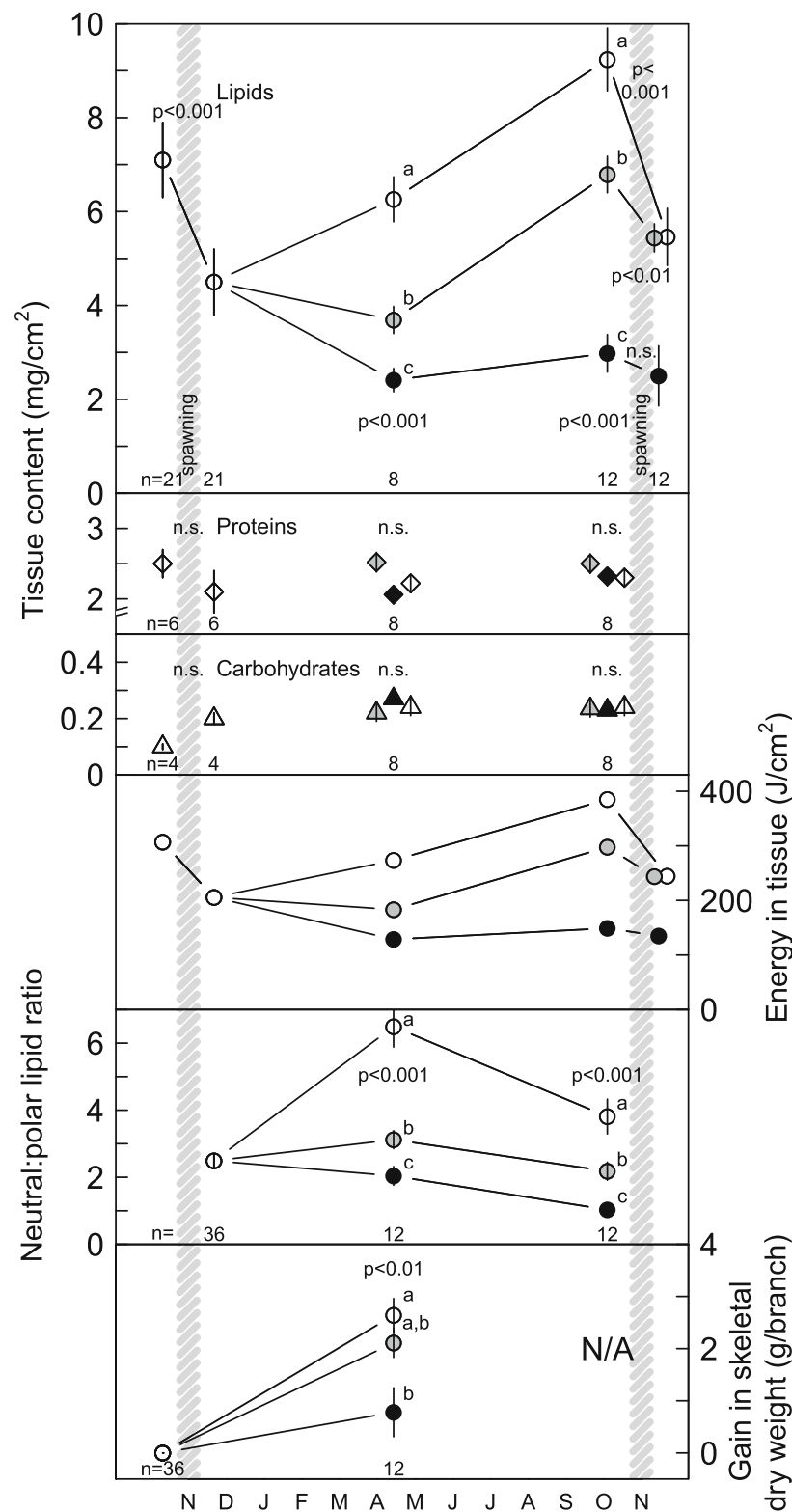

Fig. 1 Temporal patterns in tissue chemistry, tissue energy content, neutral to polar lipid ratio and gain in skeletal dry weight for unshaded (open circles), half-shaded (grey circles) and shaded (black circles) colonies of the shallow reef coral $M$. digitata at Orpheus Island over 1 year. Sample sizes are indicated at the bottom of each figure, except for tissue energy content, which was calculated based on lipid, protein and carbohydrate contents. Common lowercase letters denote treatment groups that do not differ significantly at a given sampling time, as determined by Tukey's HSD tests. $n s$ denotes non-significant differences (at 5\% level), either among treatments at a given sampling time or between sampling times within a treatment group (letters in grey hatched areas). $P$-values indicate differences, either among treatments or among sampling times within a treatment (latter in grey hatched areas). The effect of spawning on tissue composition was highly significant for lipid content $(P<0.001)$ but non-significant for carbohydrates and proteins

spawning event), lipid content of unshaded and half-shaded colonies had increased to over 9 and $7 \mathrm{mg} \mathrm{cm}^{-2}$, respectively, while shaded colonies remained at a consistently low value of around $3 \mathrm{mg} \mathrm{cm}^{-2}$. Both protein and carbohydrate levels remained unaffected by shading, varying less than 20 and $12 \%$, respectively, among light treatments (Fig. 1).

Investment into reproductive output

Lipid content decreased dramatically following the spring spawning in the years 2000 and 2001 in unshaded (control) colonies (Fig. 1, paired $t$ tests, $P<0.001$ ). Assuming no other substantial losses occurred during this time, the reproductive output in unshaded $M$. digitata calculated from lipid loss approximated 2.6 and $3.8 \mathrm{mg} \mathrm{cm}^{-2}$, corresponding to 37 and $41 \%$ of its total tissue energy content in the year 2000 and 2001, respectively. Half-shaded colonies showed a decrease in lipid content of $20 \%$ $(P<0.001)$, and shaded colonies showed no significant decrease in lipid content. None of the experimental colonies participated in the predicted minor spawning in autumn. Protein and carbohydrate content per unit surface area of tissue did not change significantly following spawning nor in response to shading, remaining around 2.5 and $0.25 \mathrm{mg} \mathrm{cm}^{-2}$ throughout the study (Fig. 1).

The ratio of neutral to polar (n:p) lipids was $2.5 \pm 0.2$ s.e. immediately after spawning in November (no pre-spawning ratio available) and increased to $6.5 \pm 0.6$ s.e. in unshaded colonies after 4 months. In contrast, the n:p ratio did not change after spawning in the half-shaded colonies and decreased from 2.5 to $2.0 \pm 0.3$ s.e. in shaded colonies (Fig. 1). After 1 year, shortly before the spring spawning event, there was a further slight decrease in $\mathrm{n}: \mathrm{p}$ ratios in both light treatments, as well as in the control colonies, scaling linearly with comparative patterns in reproductive investment (per unit surface area) among treatments.

\section{Skeletal growth}

The mean increase in skeletal dry weight during the first 4 months of the treatment was reduced significantly in the shaded $(0.78 \mathrm{~g} \pm 0.47$ s.e.) compared to the unshaded (2.64 g \pm 0.32 s.e., one-way ANOVA, $P<0.003$ ) colonies (Fig. 1). Investment into skeletal growth in halfshaded colonies was intermediate but only significantly different from fully shaded colonies.

\section{Energy acquisition}

Only maximum photosynthesis $\left(P_{m}\right)$ differed significantly between treatments: $P_{m}$ was higher in unshaded colonies than in shaded ones, which means that photosynthetic efficiency was lower in the latter at light levels greater than $1,000 \mu \mathrm{mol}$ photons $\mathrm{m}^{-2} \mathrm{~s}^{-1}$ (Table 1). Maximum 
Table $1 I_{k}, P_{m}$ and $R$-values of $M$. digitata after 4 months of altered light conditions on the reef flat of Orpheus Island

\begin{tabular}{|c|c|c|c|c|}
\hline & Unshaded & Half-shaded & Shaded & $P$-level \\
\hline$P_{m}\left(\mu \mathrm{mol} \mathrm{O} \mathrm{cm}^{-2} \mathrm{~h}^{-1}\right)$ & $2.62 \pm 0.27^{\mathrm{a}}$ & $1.99 \pm 0.18^{\mathrm{b}}$ & $1.87 \pm 0.14^{\mathrm{b}}$ & $0.037^{*}$ \\
\hline$I_{k}\left(\mu \mathrm{mol} \mathrm{m}{ }^{-2} \mathrm{~s}^{-1}\right)$ & $532.64 \pm 44.51^{\mathrm{a}}$ & $434.24 \pm 39.48^{\mathrm{a}}$ & $427.69 \pm 61.64^{\mathrm{a}}$ & $0.266^{\mathrm{ns}}$ \\
\hline$R\left(\mu \mathrm{mol} \mathrm{O} \mathrm{cm}^{-2} \mathrm{~h}^{-1}\right)$ & $-0.45 \pm 0.03^{\mathrm{a}}$ & $-0.34 \pm 0.04^{\mathrm{a}}$ & $-0.36 \pm 0.07^{\mathrm{a}}$ & $0.277^{\mathrm{ns}}$ \\
\hline
\end{tabular}

Mean values \pm standard errors are shown in the left part of the table. Common lowercase letters indicate non-significant differences. One-way Model I ANOVAs (right part of the table) testing the effect of light treatments (shaded, unshaded and half-shaded) on the parameters of the P-I curve. $N=8$ colonies. $n s$ non-significant, $* 0.05>P>0.01$

photosynthesis $P_{m}$ of half-shaded colonies did not differ significantly from values of colonies in the other two light treatments. Also, $I_{k}$ and $R$ did not vary significantly among treatments (Table 1). Generally, the model $P_{\text {net }}=P_{m}$ tan $\mathrm{h}\left(I / I_{k}\right)+R$ provided an excellent fit to the data for all runs, with $R^{2}$ values between 0.95 and 0.99 .

Energy allocation model construction and parameterisation

In order to test our hypothesis that the relative amount of energy channelled to reproduction decreases with decreasing resource availability, we analysed data on growth and reproduction using the simple model, Scope for Growth (SfG), which describes the energy balance of an organism (Warren and Davis 1967):

$\mathrm{SfG}=P_{\text {net }}+H-L$

where $P_{\text {net }}$ is the rate of net photosynthesis (including respiration), $H$ the rate of heterotrophic assimilation and $L$ the rate of energy loss through excretion.

SfG can be partitioned between energy investment into skeletal growth, $E_{C}$, tissue growth $E_{T}$ and reproduction, $E_{R}$. $E_{T}$ includes energy channelled into maintenance and storage, which we will here consider part of tissue energy investment. Expressing all terms in units of $\mathrm{J} \mathrm{cm}^{-2}$ year $^{-1}$, we obtain

$E_{\mathrm{SfG}}=E_{P \text { net }}+E_{H}-E_{L}=E_{C}+E_{T}+E_{R}$.

The energy invested into skeletal growth, $E c$, was calculated based on the energetics of accumulating skeletal dry weight ( $\Delta W_{\text {sk }}$, see methods) and extrapolated to 1 year (assuming constant skeletal growth across seasons).

To estimate energy invested into somatic tissue growth $\left(E_{T}\right)$, we assumed that all of the energy content per $\mathrm{cm}^{2}$ could be attributed to somatic tissues, from which reproductive products $\left(E_{R}\right)$ are drawn once yearly:

$E_{T}=\left[\varepsilon_{2} S_{2}-\varepsilon_{1} S_{1}\right] / S_{1}-E_{R}$

where $S$ is the colony surface area and $\varepsilon$ is the specific energy content calculated from biochemical data (lipid, protein and carbohydrate contents). Subscripts 1 and 2 denote at the beginning and end of the experimental period, respectively. Energy investment into reproduction, $E_{R}$, was estimated directly from the difference in tissue energy content before and immediately after the spawning in November 2001.

Yearly net rates of photosynthesis $\left(E_{P \text { net }}\right)$ were approximated for each light treatment during a 4-month period and extrapolated to 1 year taking variation in irradiance among seasons into account (Anthony and Connolly 2004). Treatment-specific $\mathrm{O}_{2}$ flux data were combined with light data, tide tables and specific extinction properties of light in water (methods section):

$p_{n}=\sum_{m=1}^{12} \sum_{h=0}^{24}\left(P_{m} \tanh \left(I_{t} / I_{k}\right)+R\right)$

where $P_{m}\left(\mu \mathrm{mol} \mathrm{O} \mathrm{O}_{2} \mathrm{~cm}^{-1} \mathrm{~h}^{-1}\right)$ is the maximal rate of gross photosynthesis, $I_{k}$ ( $\mu \mathrm{mol}$ photons $\mathrm{m}^{-2} \mathrm{~s}^{-1}$ ) is the point of light saturation and $R\left(\mu \mathrm{mol} \mathrm{O}_{2} \mathrm{~cm}^{-2} \mathrm{~h}^{-1}\right)$ is the rate of respiration. Net rates of photosynthesis of colonies in the unshaded, half-shaded and shaded treatments were estimated based on the input of projected light levels for each treatment. Heterotrophic energy acquisition $\left(E_{H}\right)$ was set constant for all treatments at an average value of $50 \mathrm{~J} \mathrm{~cm}^{-2}$ year $^{-1}$ (Anthony 1999). Excretion $\left(E_{L}\right)$ was not estimated but accounts for some of the residual values as discussed below.

Results of energy investment analyses indicate that the energy available from photosynthesis was reduced by almost $80 \%$ in half-shaded compared to unshaded control colonies, and that shaded colonies had a negative energy balance (Fig. 2). Of the energy available, the proportion of energy allocated to reproduction versus tissue and skeletal growth increased as resource availability decreased from high (controls) to intermediate (half-shaded) levels (from $E_{R}: E_{T}: E_{C}=11: 81: 8$ to $\left.20: 31: 49 \%\right)$. However, as resource availability decreased further between the half-shaded and shaded treatments, the absolute amount of energy allocated to reproduction decreased. At the lowest light level, energy investment to skeletal growth was still substantial $\left(35 \mathrm{~J} \mathrm{~cm}^{-2}\right.$ year $^{-1}$ ), but tissue energy content decreased and reproduction ceased. 


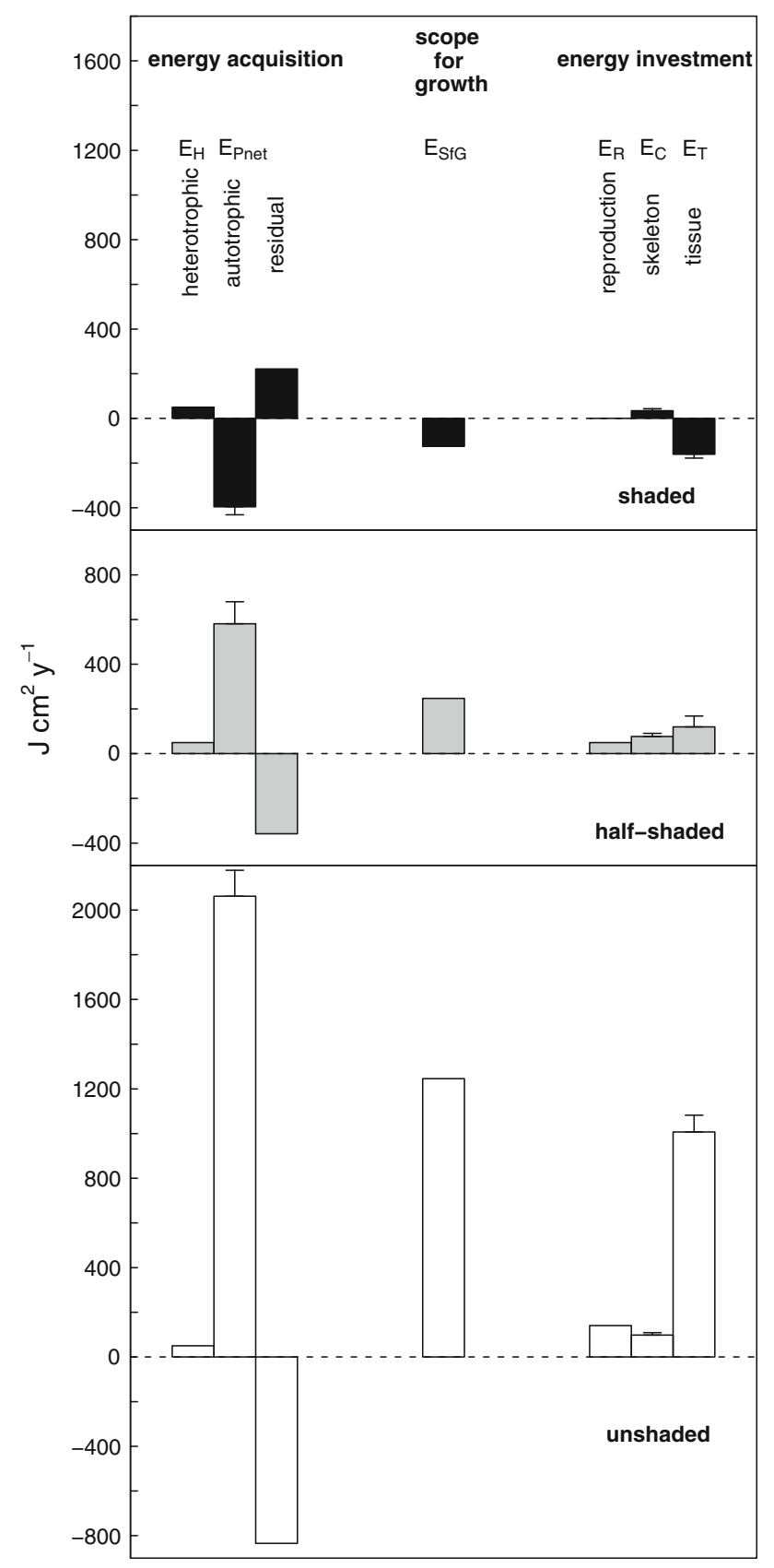

Fig. 2 Summary of energy acquisition and investment $\left(E_{\mathrm{SfG}}=\right.$ $E_{P \text { net }}+E_{h}-$ residual $=E_{C}+E_{T}+E_{R}$ ) for colonies of $M$. digitata under different light regimes. Excretion $\left(E_{L}\right)$ is not listed but could account for the unassigned excess energy (here named residual) in unshaded and half-shaded colonies. For a definition of the variables, see text. All values are in $\mathrm{J} \mathrm{cm}^{-2}$ year $^{-1}$. Standard errors are shown where appropriate. $E_{h}$ was estimated from the previous studies

\section{Discussion}

\section{Energy allocation}

Energy allocation to reproduction in the coral $M$. digitata increased at intermediate levels of resource availability but, in contrast to predictions of the terminal investment theory (Velando et al. 2006), it ceased completely at the lowest resource level. Thus, we found a convex rather than a concave relationship between resource availability and reproductive investment, a response pattern not observed previously in marine modular organisms. Specifically, in response to an $80 \%$ drop in photosynthetic energy, $M$. digitata doubled the percentage of available energy that it invested into reproductive tissue growth. However, at full shading (representing severe resource limitation), investment into reproduction ceased and tissue energy content shrank. Interestingly, skeletal growth continued at a low rate, even when resources were severely limited. With additional treatments, particularly between the ambient (control) and intermediate (20\% of ambient) light treatments, an initial decrease in reproductive allocation with reduction in energy availability might have been detected, as has been found for insects (Kaitala 1991, Ellers and van Alphen 1997). However, we did not observe a terminal reproductive event (Velando et al. 2006), even when energy budgets were negative (Fig. 2), although it should be noted that no signs of mortality were detected throughout the study. We hypothesise that the modular life form of marine invertebrates like $M$. digitata may contribute to the observed pattern of energy allocation. The chance that at least some part of a colony may survive and reproduce later may promote a strategy that prioritises survival rather than an immediate reproductive event at the cost of subsequent death of the whole colony. Because growth and maintenance of somatic tissue increases the potential for asexual reproduction, for example the potential for fragmentation, modular marine invertebrates are likely to have evolved different patterns of resource allocation under severe resource limitation than the unitary (mostly) sexually reproducing animals in the studies cited here.

Our study shows that skeletal growth is maintained, even under conditions of severe resource limitation, a pattern consistent with previous studies, which have shown that skeletal growth is relatively cheap compared to tissue growth in branching corals (Anthony and Fabricius 2000; Anthony et al. 2002). Skeletal growth is an important mechanism for extending scaffolding to support tissues and for infilling spaces in branching corals (e.g. Barnes and Chalker 1990). Maintaining this ability under low resource availability means sustaining a key fitness component at low cost. Energy allocation to tissue was more than 10 times higher than allocation to skeletal growth in unshaded colonies, whereas in half-shaded colonies, tissue investment was merely 1.5 times higher than skeletal investment. This almost seven times higher variation in tissue growth as compared to variation in skeletal growth suggests that skeletal growth is less susceptible to environmental 
variation. The same but less distinct pattern was previously reported by Anthony and Fabricius (2000), who found between 1.2 and 3 times higher variation in tissue investments than skeletal growth in shaded and unshaded G. retiformis and P. cylindrica.

Our results indicate that sexual reproduction is traded off in favour of skeletal growth in M. digitata. From our energy allocation model, we infer that by growing $1 \mathrm{~mm}$ less per year, an unshaded branch of $10 \mathrm{~cm}^{2}$ surface area could increase allocation to yearly reproduction by $26.3 \mathrm{~J} \mathrm{~cm}^{-2}$. At a growth rate of about $25 \mathrm{~mm}$ per year, this means that $4 \%$ less growth could result in a $21 \%$ increase in reproductive output. However, asexual reproduction through fragmentation may counteract the need to invest a larger proportion of energy into sexual reproduction. Overall, annual investment into sexual reproduction of almost $50 \%$ of the energy content per unit surface area of control colonies is comparable to earlier findings for corals (62\% for Pocillopora damicornis; Richmond 1987).

Control colonies that experienced ambient light levels approximately trebled their n:p ratio (to 6.5) over 4 months, indicating significant investment into storage lipids, such as reproductive products. The range of $n: p$ ratios reported here matches that found by Yamashiro et al. (1999), who report values between 2 and 4 in whole-tissue samples of 11 scleractinians. Declines in the ratio of neutral (n) to polar (p) lipids in tissues of M. digitata following periods of experimentally reduced resources clearly demonstrate that this ratio is a good predictor of the physiological status, as well as the reproductive activity, of coral tissues. In contrast to the pattern of increased n:p lipid ratios following spawning for unshaded colonies, the lack of a significant difference in the ratios of colonies experiencing resource limitation suggests that $M$. digitata was not able to rebuild its storage lipids after the November 2000 spawning in the low light treatment (Fig. 1). Our three levels of resource availability enable us to develop the following simple linear regression model between $\mathrm{n}: \mathrm{p}$ ratios (1.03, 2.18 and 3.80 for shaded, half-shaded and unshaded colonies, Fig. 1) and corresponding reproductive investments $\left(0, \quad 50\right.$ and $141 \mathrm{~J} \mathrm{~cm}^{-2}$ year $\left.^{-1}\right): E_{\text {rep }}=$ $-56.08+51.25 \times \mathrm{n}$ :p ratio. This relationship suggests that an n:p threshold ratio of around 1.5 is required before $M$. digitata is able to reproduce. The generality of this relationship, which is based on only three levels of resource limitation and one single species, merits further study for other coral species over a wider spectrum of resource limitation.

\section{Energy acquisition}

Yearly net photosynthesis $\left(E_{P \text { net, }}\right.$ measured in $\mathrm{J} \mathrm{cm}^{-2}$ ), obtained by extrapolating data measured during the four- month study, resulted in a positive energy balance in both unshaded and half-shaded colonies, but a highly negative one in the shaded treatment. The energy acquisition of unshaded colonies $\left(2,032 \mathrm{~J} \mathrm{~cm}^{-2}\right.$ year $\left.^{-1}\right)$ is approximately twofold higher than the values reported by Anthony and Fabricius (2000) for the corals Goniastrea retiformis and Porites cylindrica (between 900 and $1,200 \mathrm{~J} \mathrm{~cm}^{-2}$ year $^{-1}$ of fixed carbon) in a range of experimental light and sediment treatments. Thus, $M$. digitata is comparatively well-adapted to acquire its energy almost exclusively and effectively through photoautotrophy under ambient reef flat (i.e. high) light levels. The negative energy balance of the shaded colonies was surprising and shows that one or several terms of the energy budget were over-or underestimatedgiven that these colonies continued to invest into skeletal (and therefore tissue) growth. Even on clear days with the highest irradiance levels, net oxygen turnover was always negative for the shaded treatment. Possibly, the dark respiration measured and assumed to remain constant during the day was overestimated. This could have been due to handling stress of the colonies during the respirometry experiments, as suggested by Anthony and Fabricius (2000). Another explanation is that the light levels measured in the field were underestimated because of the large amount of refraction of light occurring in water. Deficit budgets have been reported previously in cnidarians (Tytler and Spencer Davies 1986; Spencer Davies 1991); however, in the latter study, the deficit could be fully compensated for by depletion of storage reserves from days with high light levels. Here, resources drawn from the shrinking tissue could not compensate wholly for the deficit.

In conclusion, in the reef coral $M$. digitata, the ratio of energy allocated to reproduction versus growth as a function of declining resources follows a concave curve, with a maximum at intermediate resource availability. This pattern stands in contrast to results from studies on unitary organisms. Our results highlight the need for a more detailed theoretical framework of resource allocation that accounts for the modular nature and high potential for asexual reproduction of sessile marine invertebrates. Experimental studies with more levels of resource limitation will provide further insights into how the ratio of energy channelled to reproduction versus growth varies with declining resources in modular marine organisms.

Acknowledgments We are grateful to Noël Nevers, Sarah Dalesman and Vincent Rivière for assistance in the field and to the staff of Orpheus Island Research Station. The research was supported by grants from the Australian Research Council to K.R.N.A. (A00105071) and to BLW (A 19933007) and a CRC Reef Research Award to S.L. 


\section{References}

Anthony KRN (1999) Coral suspension feeding on fine particulate matter. J Exp Mar Biol Ecol 232:85-106

Anthony KRN, Connolly SR (2004) Environmental limits to growth: physiological niche boundaries of corals along turbidity-light gradients. Oecologia 141:373-384

Anthony KRN, Fabricius KE (2000) Shifting roles of heterotrophy and autotrophy in coral energetics under varying turbidity. J Exp Mar Biol Ecol 252:221-253

Anthony KRN, Hoegh-Guldberg O (2003) Variation in coral photosynthesis, respiration and growth characteristics in contrasting light microhabitats: an analogue to plants in forest gaps and understoreys? Funct Ecol 17:246-259

Anthony KRN, Connolly SR, Willis BL (2002) Comparative analysis of energy allocation to tissue and skeletal growth in corals. Limnol Oceanogr 47:1417-1429

Bachtiar I (1994) The effect of temperature, photoperiod and fragmentation on the reproduction of mass spawning corals. Master's thesis. James Cook University, Townsville

Barnes DJ, Chalker BE (1990) Calcification and photosynthesis in reef-building corals and algae, pp. 209-257. In: Dubinsky Z (ed) Coral reefs' ecosystems of the world. V. 25. Elsevier, New York

Boggs CL (2009) Understanding insect life histories and senescence through a resource allocation lens. Funct Ecol 23:27-37

Buddemeier RW, Kinzie RA (1976) Coral growth. Oceano Mar Biol Ann Rev 14:183-225

Busalmen JP, Roura SI, Roldan H, Crupkin M (1995) Changes in lipids and biochemical properties of actomyosin from pre- and post-spawned hake (Merluccius hubbsi Marini). Comp Biochem Physiol B-Biochem Mol Biol 112:743-748

Calow P (1987) Evolutionary physiological ecology. Cambridge University Press, New York

Chalker BE (1981) Simulating light-saturation curves for photosynthesis and calcification by reef-building corals. Mar Biol 63:135-141

Chalker BE, Dunlap WE, Oliver JK (1983) Bathymetric adaptations of reef-building corals at davies reef, great barrier reef, Australia. II. Light saturation curves for photosynthesis and respiration. J Exp Mar Biol Ecol 73:37-56

Chiariello NR, Gulmon SL (1991) Stress effects on plant reproduction. In: Mooney HA, Winner WE, Pell EJ et al (eds) Response of plants to multiple stresses. Academic Press, San Diego, pp 161-188

Cullen JJ, Lesser MP (1991) Inhibition of photosynthesis by ultraviolet radiation as a function of dose and dosage rate: results for a marine diatom. Mar Biol 111:183-190

DeAngelis DL, Gross LJ (1992) Individual-based models and approaches in ecology. Chapman and Hall, New York

Edmunds PJ (2007) Physiological ecology of the clonal corallimorpharian Corynactis californica. Mar Biol 150:783-796

Edmunds PJ, Spencer Davies P (1986) An energy budget for Porites porites (Scleractinia). Mar Biol 92:339-347

Elendt BP (1989) Effects of starvation on growth, reproduction, survival and biochemical composition of Daphnia pulex. Arch Hydrobiol 116:415-433

Ellers J, van Alphen JJM (1997) Life history evolution in Asobara tabida: plasticity in allocation of fat reserves to survival and reproduction. J Evol Biol 10:771-785

Fischer B, Taborsky B, Dieckmann U (2009) Unexpected patterns of plastic energy allocation in stochastic environments. Am Nat 173:E108-E120

Fischer B, Dieckmann U, Taborsky B (2011) When to store energy in a stochastic environment. Evolution 65:1221-1232
Fisher RA (1930) The genetical theory of natural selection. Oxford University Press, Oxford

Folch J, Lees M, Sloane Stanley GH (1957) A simple method for the isolation and purification of total lipids from animal tissues. J Biol Chem 226:497-509

Goreau TF, Goreau NT (1959) The physiology of skeleton formation in corals. II. Calcium deposition by hermatypic corals under various conditions in the reef. Biol Bull Woods Hole Mass 117:239-250

Grottoli AG, Rodrigues LJ, Palardy JE (2006) Heterotrophic plasticity and resilience in bleached corals. Nature 440:1186-1189

Gutow L, Leidenberger S, Boos K, Franke HD (2007) Differential life history responses of two Idotea species (Crustacea: Isopoda) to food limitation. Mar Ecol Prog Ser 344:159-172

Harland AD, Davies PS, Fixter LM (1992) Lipid content of some caribbean corals in relation to depth and light. Mar Biol 113:357-361

Heyward AJ, Collins JD (1985) Growth and sexual reproduction in the scleractinian coral Montipora digitata (Dana). Aust J Mar Freshw Res 36(3):441-446

Jassby AD, Platt T (1976) Mathematical formulation of the relationship between photosynthesis and light for phytoplankton. Limnol Oceanogr 21:540-547

Kaitala A (1991) Phenotypic plasticity in reproductive behaviour of waterstriders: trade-offs between reproduction and longevity during food stress. Funct Ecol 5:12-18

Kirk JTO (1994) Light and photosynthesis in aquatic ecosystems, 2nd edn. Cambridge University Press, Cambridge

Leuzinger S, Anthony KRN, Willis BL (2003) Reproductive energy investment in corals: scaling with module size. Oecologia 136:524-531

Logan A, Tomascik T (1991) Extension growth rates in two coral species from high-latitude reefs of Bermuda. Coral Reefs 10:155-160

Lough JM, Barnes DJ (1997) Several centuries of variation in skeletal extension, density and calcification in massive porites colonies from the great barrier reef: a proxy for seawater temperature and a background of variability against which to identify unnatural change. J Exp Mar Biol Ecol 211:29-67

Maynard Smith J (1971) The origin and maintenance of sex. In: Williams CG (ed) Group selection. Aldine-Atherton, Chicago, pp 163-171

McCloskey LR, Wethey DS, Porter JW (1978) The measurement and interpretation of photosynthesis and respiration in reef corals. Monogr Oceanogr Methodol (SCOR-UNESCO) 4:379-396

McCloskey LR, Muscatine L, Wilkerson FP (1994) Daily photosynthesis, respiration, and carbon budgets in a tropical marine jellyfish (Mastigias sp.). Mar Biol 119:13-22

Muscatine L (1990) The role of symbiotic algae in carbon and energy flux in reef corals. In: Dubinsky Z (ed) Ecosystems of the world: coral reefs. Elsevier, Amsterdam, pp 75-87

Nespolo RF, Halkett F, Figueroa CC, Plantegenest M, Simon JC (2009) Evolution of trade-offs between sexual and asexual phases and the role of reproductive plasticity in the genetic architecture of aphid life histories. Evolution 63:2402-2412

Noonburg EG, Nisbet RM, McCauley E, Gurney WSC, Murdoch WW, De Roos AM (1998) Experimental testing of dynamic energy budget models. Funct Ecol 12:211-222

R Development Core Team (2007) R: a language and environment for statistical computing. R Foundation for Statistical Computing, Vienna

Reekie EG, Bazzaz FA et al (2005) Reproductive allocation in plants. Elsevier, Amsterdam

Richmond RH (1987) Energetic relationships and biogeographical differences among fecundity, growth, and reproduction in the reef coral pocillopora damicornis. Bull Mar Sc 41:594-604 
Riegl B, Branch GM (1995) Effects of sediment on the energy budgets of four scleractinian (Bourne 1900) and five alcyonacean (Lamouroux 1816) corals. J Exp Mar Biol Ecol 186:259-275

Rogers CS (1979) Effect of shading on coral-reef structure, function. J Exp Mar Biol Ecol 41:269-288

Spencer Davies P (1989) Short-term growth measurements of coral growth using an accurate buoyant weighing technique. Mar Biol 101:389-395

Spencer Davies P (1991) Effect of daylight variations on the energy budget of shallow-water corals. Mar Biol 108:137-144

Stearns SC (1989) Trade-offs in life-history evolution. Funct Ecol 3:259-268

Stelzer CP (2001) Resource limitation and reproductive effort in a planktonic rotifer. Ecology 82:2521-2533

Stimson JS (1987) Location, quantity and rates of change in quantity of lipids in tissue of Hawaiian hermatypic corals. Bull Mar Sc 41:889-904

Stobart B (1994) Delimiting coral species using alternative techniques: a case study. Dissertation. James Cook University, Townsville

Stobart B, Babcock RC, Willis BL (1992) Biannual spawning of three species of scleractinian coral from the great barrier reef. In: Proceedings of the 7th international coral reef symposium, vol 1 , pp 494-499

Stromgren T (1987) The effect of light on the growth rate of intertidal Acropora pulchra (Brook) from Phuket, Thailand, lat. 8N. Coral Reefs 6:43-47
Tytler EM, Spencer Davies P (1986) The budget of photosynthetically derived energy in the Anemonia-sulcata symbiosis. J Exp Mar Biol Ecol 99:257-270

Velando A, Drummond H, Torres R (2006) Senescent birds redouble reproductive effort when ill: confirmation of the terminal investment hypothesis. P Roy Soc Lond B Bio 273:1443-1448

Ward S, Harrison P (2000) Changes in gametogenesis and fecundity of acroporid corals that were exposed to elevated nitrogen and phosphorus during the ENCORE experiment. J Exp Mar Biol Ecol 246:179-221

Warren CE, Davis GE (1967) Laboratory studies on the feeding, bioenergetics and growth of fish. In: Gerking SD (ed) The biological basis for freshwater fish production. Blackwell Scientific, Oxford, pp 175-214

Wellington GM (1982) An experimental analysis of the effects of light and zooplankton on coral zonation. Oecologia 52:311-320

Williams GC (1966) Natural selection, the cost of reproduction, and a refinement of Lack's principle. Am Nat 100:687-690

Withers PC (1992) Comparative animal physiology. Saunders College Publishing, Orlando

Yamashiro H, Oku H, Higa H, Chinen I, Sakai K (1999) Composition of lipids, fatty acids and sterols in Okinawan corals. Comp Biochem Physiol B-Biochem Mol Biol 122:397-407

Zera AJ, Harshman LG (2001) The physiology of life history tradeoffs in animals. Annu Rev Ecol Syst 32:95-126

Zubay G (1983) Biochemistry, 2nd edn. Addison-Wesley Publishing Company, Reading, Massachusetts 